\title{
Proceeding
}

Supplementary Issue: Rio 2016 Olympic Games First Anniversary Special Edition. Olympic Studies Forum, 4-5 August 2017. Santa Úrsula University. Rio de Janeiro, Brazil

\section{Created olympic image: The Rio Olympics 2016 from the perspective of international high-quality print media}

\author{
ERIK ROHDE \\ Institute of Sport Science, Technical University of Kaiserslautern, Germany
}

\begin{abstract}
The modern Olympic Games are more and more observed by the international media. The transported information flood of the media and the simultaneously increased dependence of the recipients on media communications in our modern times are certainly dangerous. Overloading and direct subjugation can arise opinions and views, which are based on misinterpreted and often deliberately externally driven representations. It is therefore even more important, to deal with the available information objectively. In this way, a true-faith creation of images can be approached. Print media is also given an influential role in the transmission of information and image formation. For this reason, the present study focused on examining different aspects of the 2016 Olympic Games in Rio de Janeiro in the background reporting of four selected, international quality newspapers. Central questions were, whether Rio de Janeiro had organized good or bad Games, and whether Olympic principles were followed in accordance with the Olympic Charter as well as the Olympic values of Pierre de Coubertin and Hans Lenk. A differentiated examination grid was developed, detecting eleven formal content categories from all the individual articles, preliminary reports, reports during the Olympic Games and subsequently, over a fixed examination period of 127 days. The evaluation illustrates, that for instance, the Brazilian people as hosts, the host city, or the organization of the Olympic Games, rarely received positive reviews in the newspapers. Specific Olympic values, as represented by Coubertin and Lenk, appeared to be impaired in the media evaluations. Key words: OLYMPIC GAMES, ETHIC VALUES, SPORT PRINCIPLES, COUBERTIN, NEWSPAPER CONTENT ANALYSIS, LEGACY.
\end{abstract}

Cite this article as:

Rohde, E. (2018). Created olympic image: The Rio Olympics 2016 from the perspective of international high-quality print media. Journal of Human Sport and Exercise, 13(1proc), S53-S68. doi:https://doi.org/10.14198/jhse.2018.13.Proc1.06

\footnotetext{
Corresponding author. Institute of Sport Science, Technical University of Kaiserslautern, Germany.

E-mail: erik.rohde.5@gmail.com

Supplementary Issue: Rio 2016 Olympic Games First Anniversary Special Edition. Olympic Studies Forum, 4-5 August 2017. Santa Úrsula University. Rio de Janeiro, Brazil.

JOURNAL OF HUMAN SPORT \& EXERCISE ISSN 1988-5202

(c) Faculty of Education. University of Alicante

doi:10.14198/jhse.2018.13.Proc1.06
} 


\section{INTRODUCTION}

Since Baron Pierre de Coubertin has introduced the modern Olympic Games, 123 years ago, this special revival has led to an almost ever-increasing interest among viewers and the media. Newspapers, radio, television, and more recently digital media, contributed a significant share to the development of the current Games. With their portrayals, in the form of reports, messages, and transmissions, they convey intentional, or not wanted impressions and images of what is happening in the sight of the five rings among their recipients. Thus, they have a direct influence on opinion creation and shaping of images. Because of that, regulations for compliance with media rules at the Olympic Games have been issued in the past, as Adi (2013) illustrates. Particularly today, the participants of Olympic competitions receive a guaranteed, broad public and media interest. The same applies to venues, respectively hosts, of the Olympic Games, or the International Olympic Committee, IOC. In the spotlight of increased media attention, everyone wants to show and offer the best possible picture of oneself, or, in a controlled manner, to achieve that through this favor. After all, a good image is also good for business. But the prestige of the Olympic Games, where the best athletes on earth come together peacefully, every four years, and show their achievements to the world in fair competition, has suffered severely. For more than a decade, today's Olympic Movement has become increasingly unstable. The healing facade is crumbling, the Olympic reputation is ruined and trashed. Political, economic, and power-hungry as well as power-driven, extrinsic and intrinsic influences, have significantly contributed to that fact. The glittering days, when Olympic cities have literally torn themselves to host the Olympic Games, and when athletes, in the chivalrous manner, always emphasized by Coubertin (1935), have achieved honorable fame and self-knowledge, are gone. Corruption and doping are now dominating the global sport, also the Olympic one. The confidence in officials and athletes is increasingly diminishing. The once, great and magnificent Olympic image, in the minds of many people, is destroyed. Political and economic interests have always been there at modern Olympic Games, and they cannot be avoided in our modern, globalized world, as Chappelet (2014) states. But never before, the discrepancy, between adherence to ethic, traditional values and rules, moreover, simultaneously generated profits, has been greater than nowadays. Meanwhile, the IOC money machine is buzzing. Despite the current bad image situation, contracts are blithely signed or extended with major global sponsors, and individual media institutions are granted privileges for proper payment, which may directly influence the Olympic event. Lennartz (2014) warned, that the Games are losing their identification, because the people see the symbol of the rings no longer as an idea of Coubertin to unite nations, but more as a permanent running machine to print money. Currently, more and more athletes express their displeasure with the present developments in these days, but IOC just appeases. The media are increasingly informing on this hodgepodge of truth, lies and deception - not always through an objective, uninfluenced and independent reporting. Global media, themselves, are also in disrepute today. They are often accused by critics, of producing a too subjective, boulevardized and sensation-focused coverage. Recent new releases, such as 'fake news', to create special opinions, have let this impression increasingly germinate. Established media, like newspapers, must fight against these allegations. Considering the fact, that message communication is always subjected to individual selection and distortion processes, as Schulz (2008) explains, it is even more important to meet momentous quality criteria for message transport, especially, about global events of high public interest. For those reasons, it is of great interest to analyze, how the international print media has evaluated and represented the Olympic Games in Rio de Janeiro 2016. The main aim of this study was, to investigate the reality constructed by the mass media, as Luhmann (1996) has discussed in detail, and not the primary reality, over chosen aspects of the Rio Olympics in the background reporting of international print media. Central questions were: whether organizers, hosts, as the city Rio de Janeiro or the Brazilian people, and finally the IOC, had taken their chance to present themselves to the world as good hosts, respectively good operators? Have they organized good or bad Games? Were Olympic principles and Olympic values followed 
in accordance with Olympic Charter (IOC, 2017), Pierre de Coubertin (1910) and Hans Lenk (1972)? Based on the results of this investigation, conclusions can be drawn, on the one hand, regarding the medial view of the Games, and on the other, concerning various aspects of the entire Olympic Movement.

\section{MATERIAL AND METHODOLOGY}

The analysis was carried out in accordance with the methodology of thesis work by Gros (2001) and Fritzler (2015). Both investigations dealt with the print media presentation of certain aspects of the Summer Olympics 2000 in Sydney, Australia, and the Winter Olympics 2014 in Sochi, Russia. On this methodological basis, the presentation of the Olympic Summer Games 2016 in Rio de Janeiro, in the background reporting of the following four selected, international daily newspapers, was examined: Frankfurter Allgemeine Zeitung, FAZ, Germany; Neue Zürcher Zeitung, NZZ, Switzerland; The New York Times, NYT, United States of America; Folha de São Paulo, FSP, Brazil. Thesis work by Rohde (2017), with previously three investigated media, flowed into this investigation, and was expanded by a fourth quality newspaper from Brazil. Every newspaper represents a high quality, influential, independent, and opinion-critical medium in its own country.

\section{Measures and Procedures}

For the analysis of the individual communication contents in the print media, the method of quantitative and qualitative content analysis, as described by Früh (1981), was used. The flow chart was based on the comments and explanations by Mayring (1983). The data was generated by using the self-developed category system of Rohde (2017), which is specifically oriented on the examination material. Moreover, it consists of eight formal and three content categories, which are subdivided into further subunits. Each contribution received a coding sheet, that comprised 27 variables. Up to nine coding sheets per article could be recorded. The investigation period covered a total of 127 days. The period was divided into three phases: preliminary coverage, 100 days prior to the start of the Olympic Games, main reporting of seventeen days during, and the follow-up reporting, ten days after the Games. A full survey of all articles in total print media was accomplished. According to special access criteria, set out by ibid. (2017), individual articles from all categories of the print media were selected. Result-oriented sports reports, graphics and letters to the editor, were not included in the selection. From this pool of articles, substantive contributions, which met the thematic access criteria, were selected from the articles and transcribed into corresponding numerical codes, using the coding sheet and the developed category system. Afterwards, these generated digit codes were transferred to normal Excel program for further analysis. The coding involved a total of seven persons. FAZ, NZZ and NYT were edited by one coder, in this mentioned order, and the Brazilian newspaper was coded by a total of six coders, all native Portuguese speakers. An intra-coder reliability test, with thirty articles, ten of each newspaper, in a ten-week interval, was only performed during the first data collection by ibid. (2017), and it revealed a high retest-reliability value, according to Krippendorff (1981), of $R=.87$. However, an intercoder reliability test, on the transcription of the Brazilian newspaper, was not carried out. The investigation units, contributions from the articles, were recorded in the following order. First the eight formal categories were recorded: each contribution received an ongoing sheet recognition, was classified according to the period, pre-, main- and post-reporting, as well as medium. Furthermore, the date was recorded, and after that the contribution number was assigned. Subsequently, the source or origin of a contribution, with twelve possibilities of classification, the style of the article, with nine coding options, and finally, the topic of the article, with eleven different thematic issues, were chosen. In the next step, the three content categories were covered. First, the presentation tendency of the contribution to the four areas Olympic Games in general, the Olympic city Rio de Janeiro, the Brazilians as hosts, and the IOC. This content category was evaluated on a five-level Likert-scale, based on Likert (1932), from very positive, positive, neutral and ambiguous, negative, to very negative. Subsequently, the contributions were investigated on special topics they dealt with. The 
classification took place into subject areas, with eleven options, which contained, overall, 93 thematic subcategories. These were thus rated, on a similar aforementioned five-level Likert-scale, as they occurred with their valuation in the newspaper. Up to three superficial themes could be encoded per contribution, in order of their importance. Finally, there was a review of statements in the text messages, by sixteen predefined allegations, on the four beforementioned thematic areas. A statement was investigated to its direction, if it appears affirmatively or negatively, as well as to its author(s), by up to eleven different groups of persons. A maximum of three preformulated statements could be recorded in a contribution.

\section{RESULTS}

A total number of 1,235 articles were recorded in each of the 127 editions of the four newspapers. 1,711 coding sheets could be recorded. In all, more than 40,000 encoding entries were noted. Most of the articles were found during the main period, when the Games took place. In contrast to that, the majority of coding sheets, respectively contributions, could be detected before the start of the Olympic Games (Table 1).

Table 1. Distribution of articles and coding sheets in the newspapers in all periods of analysis

\begin{tabular}{|c|c|c|c|c|c|c|c|c|c|c|c|c|c|c|c|c|}
\hline \multirow[t]{3}{*}{ paper } & \multicolumn{4}{|c|}{ preliminary reporting } & \multicolumn{4}{|c|}{ main reporting } & \multicolumn{4}{|c|}{ follow-up reporting } & \multicolumn{4}{|c|}{ total reporting } \\
\hline & \multicolumn{2}{|c|}{ articles } & \multicolumn{2}{|c|}{ coding sheets } & \multicolumn{2}{|c|}{ articles } & \multicolumn{2}{|c|}{ coding sheets } & \multicolumn{2}{|c|}{ articles } & \multicolumn{2}{|c|}{ coding sheets } & \multicolumn{2}{|c|}{ articles } & \multicolumn{2}{|c|}{ coding sheets } \\
\hline & $\mathrm{n}^{1}$ & $\%$ & $n^{2}$ & $\%$ & $n^{1}$ & $\%$ & $n^{2}$ & $\%$ & $n^{1}$ & $\%$ & $n^{2}$ & $\%$ & $n^{1}$ & $\%$ & $n^{2}$ & $\%$ \\
\hline FAZ & 140 & 26.3 & 336 & 41.1 & 148 & 26.2 & 243 & 33.8 & 29 & 21.0 & 55 & 31.6 & 317 & 25.7 & 634 & 37.0 \\
\hline NZZ & 115 & 21.6 & 153 & 18.7 & 65 & 11.5 & 87 & 12.0 & 12 & 8.7 & 17 & 9.8 & 192 & 15.6 & 257 & 15.0 \\
\hline NYT & 138 & 26.0 & 170 & 20.8 & 100 & 17.7 & 117 & 16.3 & 34 & 24.6 & 39 & 22.4 & 272 & 22.0 & 326 & 19.1 \\
\hline FSP & 139 & 26.1 & 158 & 19.4 & 252 & 44.6 & 273 & 37.9 & 63 & 45.7 & 63 & 36.2 & 454 & 36.7 & 494 & 28.9 \\
\hline Total & 532 & 100 & 817 & 100 & 565 & 100 & 720 & 100 & 138 & 100 & 174 & 100 & 1235 & 100 & 1711 & 100 \\
\hline
\end{tabular}

Considering the source of a contribution, most of the communication content emerges by own journalists, that clarifies the quality of the papers. FSP has a much lower use of agency material, and has published significantly more contributions from guest authors, than the other media (Table 2). 
Table 2. Distribution of sources or origin of contributions in the print media

\begin{tabular}{|c|c|c|c|c|c|}
\hline source & $\begin{array}{c}\text { FAZ } \\
(\mathrm{n}=634) \\
\%\end{array}$ & $\begin{array}{c}\text { NZZ } \\
(\mathrm{n}=257) \\
\%\end{array}$ & $\begin{array}{c}\text { NYT } \\
(\mathrm{n}=326) \\
\%\end{array}$ & $\begin{array}{c}\text { FSP } \\
(\mathrm{n}=494) \\
\%\end{array}$ & $\begin{array}{c}\text { Total (4) } \\
(\mathrm{n}=1711) \\
\%\end{array}$ \\
\hline independent contribution (Journalist / Correspondent) & 73.4 & 68.7 & 68.9 & 71.4 & 71.2 \\
\hline independent contribution (guest author) & 1.1 & 6.1 & 1.9 & 19.2 & 7.4 \\
\hline dpa (German press agency) & 18.1 & - & 15.5 & 0.2 & 9.1 \\
\hline AP (Associated Press) & - & 11.7 & 0.4 & 1.4 & 2.7 \\
\hline reuters & - & 12.0 & 0.8 & 0.6 & 2.6 \\
\hline sid (sports information service) & - & - & 0.8 & - & 0.1 \\
\hline AFP (Agence France Press) & 0.5 & 0.6 & 2.7 & 0.4 & 0.8 \\
\hline sda (Swiss dispatch agency) & - & - & 3.5 & - & 0.5 \\
\hline UP (United Press) / UPI (United Press International) & - & - & - & 0.6 & 0.2 \\
\hline several agencies / sources & 6.9 & 0.9 & 5.1 & 1.6 & 4.0 \\
\hline no information & - & - & 0.4 & 3.0 & 0.9 \\
\hline other source(s) & - & - & - & 1.6 & 0.5 \\
\hline total & 100 & 100 & 100 & 100 & 100 \\
\hline
\end{tabular}

$n=$ quantity, (number of coding sheets); \% = proportion in percent.

Table 3. Distribution of the presentation or style of an article in the print media

\begin{tabular}{|c|c|c|c|c|c|}
\hline article style & $\begin{array}{c}\text { FAZ } \\
(n=634) \\
\%\end{array}$ & $\begin{array}{c}\text { NZZ } \\
(\mathrm{n}=257) \\
\%\end{array}$ & $\begin{array}{c}\text { NYT } \\
(\mathrm{n}=326) \\
\%\end{array}$ & $\begin{array}{c}\text { FSP } \\
(\mathrm{n}=494) \\
\%\end{array}$ & $\begin{array}{c}\text { Total }(4) \\
(\mathrm{n}=1711) \\
\%\end{array}$ \\
\hline message / (short) / report / news flash & 24.8 & 23.7 & 29.5 & 55.3 & 34.3 \\
\hline contribution (with subjective coloration) & 52.1 & 43.2 & 47.9 & 15.0 & 39.2 \\
\hline comment / gloss & 6.3 & 13.6 & 4.9 & 1.2 & 5.7 \\
\hline interview & 0.9 & 1.2 & 0.3 & 3.0 & 1.5 \\
\hline reportage / feature & 2.5 & 1.6 & 2.8 & 17.2 & 6.7 \\
\hline portrait & 1.3 & - & 1.2 & 3.2 & 1.6 \\
\hline documentation & 0.6 & 1.9 & 0.9 & 0.2 & 0.8 \\
\hline criticism / appeal / leading article & 8.2 & 1.2 & 11.0 & 4.3 & 6.5 \\
\hline others (column / essay / ... ) & 3.3 & 13.6 & 1.5 & 0.6 & 3.7 \\
\hline total & 100 & 100 & 100 & 100 & 100 \\
\hline
\end{tabular}

$n=$ quantity, (number of coding sheets); \% = proportion in percent.

In addition to check the quality of the various newspapers, furthermore, the style of contributions, respectively articles, were recorded. This examination shows, that most of the published articles in FAZ, NYT and NZZ have a subjective coloration, which means an increased proportion of opinion critical contributions. These newspapers also contain a higher proportion of critical, oriented article forms than the FSP newspaper. Latter rather stands out, due to its enormous proportion of factual contributions, short reports and reportages, or interviews (Table 3). In the print media analysis of the Rio Games, a closer look took place at individual 
subjects. It turns out, that the eleven subject areas, in the reporting of the print media, could be encountered with varying frequency. A clear thematic focus at FAZ, NZZ und NYT was doping. FAZ, in particular, devoted a third of its contributions to this topic. On the other hand, the FSP drew her focus on the organization of the Games. The subject doping played only a minor role in its coverage. Furthermore, its reports were more influenced by political, economic, and security issues (Table 4). In this qualitative content analysis, a greater interest was placed on the investigation of the general presentation of the 2016 Olympic Games, in all print media, as well as on the host city Rio de Janeiro, the hosting Brazilians, and the IOC. Overall, the Brazilian daily newspaper, generally, rated the Olympic Games, tendentially and significantly better in its background reporting, than the rest of the print media. In the reporting of NZZ, NYT and especially the FAZ, the negative representations to this investigative area outweigh (Table 5).

Table 4. Main subjects in the reporting of the print media

\begin{tabular}{|c|c|c|c|c|c|c|c|c|c|c|}
\hline \multirow[t]{2}{*}{ subject } & \multicolumn{2}{|c|}{ FAZ } & \multicolumn{2}{|c|}{ NZZ } & \multicolumn{2}{|c|}{ NYT } & \multicolumn{2}{|c|}{ FSP } & \multicolumn{2}{|c|}{ Total (4) } \\
\hline & $\mathrm{n}$ & $\%$ & $\mathrm{n}$ & $\%$ & $\mathrm{n}$ & $\%$ & $\mathrm{n}$ & $\%$ & $\mathrm{n}$ & $\%$ \\
\hline Rio / hosts & 125 & 19.7 & 66 & 25.7 & 72 & 22.1 & 62 & 12.6 & 325 & 19.0 \\
\hline IOC & 79 & 12.5 & 11 & 4.3 & 9 & 2.8 & 11 & 2.2 & 110 & 6.4 \\
\hline doping & 212 & 33.4 & 72 & 28.0 & 91 & 27.9 & 36 & 7.3 & 411 & 24.0 \\
\hline culture & 13 & 2.0 & 2 & 0.8 & 8 & 2.4 & 30 & 6.1 & 53 & 3.1 \\
\hline organisation & 31 & 4.9 & 25 & 9.7 & 46 & 14.1 & 93 & 18.8 & 195 & 11.4 \\
\hline politics & 35 & 5.5 & 11 & 4.3 & 11 & 3.4 & 49 & 9.9 & 106 & 6.2 \\
\hline economy & 31 & 4.9 & 12 & 4.7 & 11 & 3.4 & 42 & 8.5 & 96 & 5.6 \\
\hline ecology & 10 & 1.6 & 5 & 1.9 & 15 & 4.6 & 16 & 3.2 & 46 & 2.7 \\
\hline safety & 25 & 4.0 & 27 & 10.5 & 18 & 5.5 & 62 & 12.6 & 132 & 7.7 \\
\hline scandals & 40 & 6.3 & 12 & 4.7 & 36 & 11.0 & 60 & 12.1 & 148 & 8.7 \\
\hline others & 33 & 5.2 & 14 & 5.4 & 9 & 2.8 & 33 & 6.7 & 89 & 5.2 \\
\hline total & 634 & 100 & 257 & 100 & 326 & 100 & 494 & 100 & 1711 & 100 \\
\hline
\end{tabular}

Table 5. Representation tendency of the Olympic Games in Rio de Janeiro 2016 by the print media

\begin{tabular}{|c|c|c|c|c|c|}
\hline tendency & $\begin{array}{c}\text { FAZ } \\
(n=591) \\
\%\end{array}$ & $\begin{array}{c}\text { NZZ } \\
(n=228) \\
\%\end{array}$ & $\begin{array}{c}\text { NYT } \\
(\mathrm{n}=301) \\
\%\end{array}$ & $\begin{array}{c}\text { FSP } \\
(\mathrm{n}=339) \\
\%\end{array}$ & $\begin{array}{c}\text { Total (4) } \\
(\mathrm{n}=1459) \\
\%\end{array}$ \\
\hline very positive & 1.4 & 3.9 & 2.0 & 18.0 & 5.8 \\
\hline positive & 6.9 & 7.0 & 9.0 & 21.2 & 10.7 \\
\hline neutral / ambiguous & 26.7 & 30.3 & 25.2 & 18.9 & 25.1 \\
\hline negative & 39.3 & 29.4 & 42.9 & 22.1 & 34.5 \\
\hline very negative & 25.7 & 29.4 & 20.9 & 19.8 & 23.9 \\
\hline total & 100 & 100 & 100 & 100 & 100 \\
\hline
\end{tabular}


The reflection of the representation of Rio de Janeiro, as the host city of the Olympic Games in the four international quality newspapers, shows almost a similar distribution of media assessments and evaluations (Table 6), like presented in the table of the Olympic Games in general (Table 5).

Table 6. Representation tendency of the Olympic host city Rio de Janeiro by the print media

\begin{tabular}{l|cccc|c}
\hline tendency & $\begin{array}{c}\text { FAZ } \\
(\mathrm{n}=259) \\
\%\end{array}$ & $\begin{array}{c}\text { NZZ } \\
(\mathrm{n}=132) \\
\%\end{array}$ & $\begin{array}{c}\text { NYT } \\
(\mathrm{n}=188) \\
\%\end{array}$ & $\begin{array}{c}\text { FSP } \\
(\mathrm{n}=296) \\
\%\end{array}$ & $\begin{array}{c}\text { Total (4) } \\
(\mathrm{n}=875) \\
\%\end{array}$ \\
\hline very positive & 3.9 & 6.8 & 3.7 & 21.6 & 10.3 \\
positive & 10.4 & 10.6 & 9.1 & $\mathbf{2 3 . 0}$ & 14.4 \\
neutral / ambiguous & 19.3 & 22.0 & 15.4 & 15.9 & 17.7 \\
negative & $\mathbf{3 8 . 2}$ & 28.8 & 34.0 & 20.6 & $\mathbf{2 9 . 9}$ \\
very negative & 28.2 & $\mathbf{3 1 . 8}$ & $\mathbf{3 7 . 8}$ & 18.9 & 27.7 \\
\hline total & 100 & 100 & 100 & 100 & 100
\end{tabular}

Particularly in the reports of FSP, the city is represented rather positive, contrary to the predominantly negative contributions in the other three newspapers. Especially, the American NYT draws to its recipients an immediately negative image of the, admittedly paradoxical sounding expression in this context, 'cidade maravilhosa', the 'wonderful city'. The analysis topic 'Brazilians as hosts', received a neutral to negative image representation. However, once again, the FSP, with more than half of its messages and contributions to the hosts, has left a positive to very positive impression on its readers, completely contrary in comparison to FAZ in this context, which express its readers, again, in more than half of its messages, the Brazilian compatriots rather negative, or even very negative (Table 7).

Table 7. Representation tendency of the Brazilians as hosts by the international print media

\begin{tabular}{l|cccc|c}
\hline tendency & $\begin{array}{c}\text { FAZ } \\
(\mathrm{n}=203)\end{array}$ & $\begin{array}{c}\text { NZZ } \\
(\mathrm{n}=99)\end{array}$ & $\begin{array}{c}\text { NYT } \\
(\mathrm{n}=117)\end{array}$ & $\begin{array}{c}\text { FSP } \\
(\mathrm{n}=171)\end{array}$ & $\begin{array}{c}\text { Total (4) } \\
(\mathrm{n}=590)\end{array}$ \\
\hline very positive & 5.9 & 7.1 & 8.5 & $\mathbf{2 6 . 3}$ & 12.5 \\
positive & 12.8 & 6.0 & 12.8 & 24.0 & 14.9 \\
neutral / ambiguous & 27.6 & $\mathbf{3 8 . 4}$ & $\mathbf{4 1 . 9}$ & 15.2 & $\mathbf{2 8 . 7}$ \\
negative & $\mathbf{3 7 . 0}$ & 26.3 & 18.0 & 20.5 & 26.6 \\
very negative & 16.7 & 22.2 & 18.8 & 14.0 & 17.3 \\
\hline total & 100 & 100 & 100 & 100 & 100 \\
& $n=$ quantity, (number of contributions); \% = proportion in percent. &
\end{tabular}

By taking a closer look at the representation of the IOC, it is striking, that the evinced valuations are of significantly more valuable weighting in the reporting of FAZ, NZZ and FSP, than in the coverage of NYT. Latter paper, practices itself a little more neutral. In contrast to last point, most of media contributions in FAZ, with good two-thirds of its whole messages, as well as the tidings by FSP and NZZ, each with more than half of their contributions, have been negative or very negative (Table 8). 
Table 8. Representation tendency of the IOC in the reporting by the international print media

\begin{tabular}{l|cccc|c}
\hline tendency & $\begin{array}{c}\text { FAZ } \\
(\mathrm{n}=380) \\
\%\end{array}$ & $\begin{array}{c}\text { NZZ } \\
(\mathrm{n}=87)\end{array}$ & $\begin{array}{c}\text { NYT } \\
(\mathrm{n}=100)\end{array}$ & $\begin{array}{c}\text { FSP } \\
(\mathrm{n}=79)\end{array}$ & $\begin{array}{c}\text { Total (4) } \\
(\mathrm{n}=646)\end{array}$ \\
\hline very positive & 1.3 & 12.6 & 8.0 & 10.1 & 5.0 \\
positive & 5.5 & 10.4 & 11.0 & 16.4 & 8.3 \\
neutral / ambiguous & 24.7 & 24.1 & $\mathbf{4 0 . 0}$ & 20.3 & 26.5 \\
negative & 33.7 & 19.6 & 22.0 & 24.1 & 28.8 \\
very negative & $\mathbf{3 4 . 8}$ & $\mathbf{3 3 . 3}$ & 19.0 & $\mathbf{2 9 . 1}$ & $\mathbf{3 1 . 4}$ \\
\hline total & 100 & 100 & 100 & 100 & 100
\end{tabular}

$n=$ quantity, (number of contributions); $\%=$ proportion in percent.

Table 9. Valuation 'Olympic Games in its function of mediating basic social values (e.g. respect / tolerance / cosmopolitanism) with regard to international understanding' through the print media

\begin{tabular}{l|cccc|c}
\hline valuation & $\begin{array}{c}\text { FAZ } \\
(\mathrm{n}=82)\end{array}$ & $\begin{array}{c}\text { NZZ } \\
(\mathrm{n}=20)\end{array}$ & $\begin{array}{c}\text { NYT } \\
(\mathrm{n}=26)\end{array}$ & $\begin{array}{c}\text { FSP } \\
(\mathrm{n}=44)\end{array}$ & $\begin{array}{c}\text { Total (4) } \\
(\mathrm{n}=172)\end{array}$ \\
& $\%$ & $\%$ & $\%$ & $\%$ & $\%$ \\
\hline pronounced positive & 20.7 & 30 & 7.7 & $\mathbf{3 8 . 6}$ & 24.4 \\
positive & 7.3 & 5 & 19.2 & 22.7 & 12.8 \\
neutral / ambiguous & 17.1 & - & 11.5 & 15.9 & 14.0 \\
negative & 12.2 & 15 & 7.7 & 15.9 & 12.8 \\
pronounced negative & $\mathbf{4 2 . 7}$ & $\mathbf{5 0}$ & $\mathbf{5 3 . 9}$ & 6.8 & $\mathbf{3 6 . 0}$ \\
\hline total & 100 & 100 & 100 & 100 & 100 \\
& $n=$ quantity, (number of contributions); \% & proportion in percent. &
\end{tabular}

From the list of subjects, with a total of 93 sub-topics, only a few important ones can be presented. Table nine above, points out, how the newspapers assess the role of the Olympic Games, in conveying important social core values in their contributions. In this context, FSP estimates the Games, in its function as value brokers and bridge builders, pronounced positive. The other print media contrast in this thematic area from FSP. They rate the Games, particularly, negative or pronounced negative, each with at least more than half of its contributions. Another important theme, related to Coubertin's Olympic leading values, is the respect and appreciation of spectators, not just for athletic demonstrations of their own compatriots, but rather more to athletic performances of participants from other nations. Table ten illustrates, that this was anything but complied by the Brazilian audience at the Olympic Games in Rio de Janeiro. All print media rate the behavior pronounced negative. 
Table 10. Behavior of Brazilian spectators against athletes of other nations (respect / fairness)

\begin{tabular}{l|cccc|c}
\hline valuation & $\begin{array}{c}\text { FAZ } \\
(\mathrm{n}=7)\end{array}$ & $\begin{array}{c}\text { NZZ } \\
(\mathrm{n}=6)\end{array}$ & $\begin{array}{c}\text { NYT } \\
(\mathrm{n}=7)\end{array}$ & $\begin{array}{c}\text { FSP } \\
(\mathrm{n}=12)\end{array}$ & $\begin{array}{c}\text { Total (4) } \\
(\mathrm{n}=32) \\
\%\end{array}$ \\
\hline pronounced positive & $\%$ & $\%$ & $\%$ & $\%$ & $\%$ \\
positive & - & - & 14.3 & 8.3 & 6.3 \\
neutral / ambiguous & - & - & - & 25 & 9.3 \\
negative & 14.3 & - & - & 8.3 & 6.3 \\
pronounced negative & - & 16.7 & - & $\mathbf{3 3 . 4}$ & 15.6 \\
\hline total & $\mathbf{8 5 . 7}$ & $\mathbf{8 3 . 3}$ & $\mathbf{8 5 . 7}$ & 25 & $\mathbf{6 2 . 5}$ \\
\hline & 100 & 100 & 100 & 100 & 100
\end{tabular}

$n=$ quantity, (number of contributions); \% = proportion in percent.

The final subject, deals with the newspapers' assessment of the 'influence of the media on the Rio Olympics' in their contributions. Although, the generated data admittedly turns out to be somewhat underrepresented, nevertheless, table eleven shows that the Brazilian newspaper valuates the media influence on the sport spectacle more positive than FAZ. Besides this, NZZ and NYT are closer to the FAZ rating, albeit being a little more neutral. Overall, the valuation of this aspect seems negative.

Table 11. Influence of media institutions (e.g. TV broadcasters) on the Olympic Games

\begin{tabular}{l|cccc|c}
\hline valuation & $\begin{array}{c}\text { FAZ } \\
(\mathrm{n}=12)\end{array}$ & $\begin{array}{c}\text { NZZ } \\
(\mathrm{n}=4)\end{array}$ & $\begin{array}{c}\text { NYT } \\
(\mathrm{n}=4)\end{array}$ & $\begin{array}{c}\text { FSP } \\
(\mathrm{n}=8)\end{array}$ & $\begin{array}{c}\text { Total (4) } \\
(\mathrm{n}=28) \\
\%\end{array}$ \\
\hline pronounced positive & $\%$ & $\%$ & $\%$ & $\%$ & 10.7 \\
positive & - & - & - & $\mathbf{3 7 . 5}$ & 3.5 \\
neutral / ambiguous & - & - & - & 12.5 & 28.6 \\
negative & 25 & $\mathbf{7 5}$ & $\mathbf{5 0}$ & - & $\mathbf{2 8 . 6}$ \\
pronounced negative & $\mathbf{4 1 . 7}$ & - & 25 & 25 & 28.6 \\
\hline total & 33.3 & 25 & 25 & 25 & 100 \\
& 100 & 100 & 100 & 100 &
\end{tabular}

Within this study, a review was performed on various, predefined statements, about the Olympic Games in Rio 2016, in the articles. Though, different results between the individual print media can be inferred from extensive table twelve on the next page. Therein, for example, the daily newspaper FSP affirms the two statements on economic benefits for the population, or the safety guarantee for athletes and visitors at the Games, while the other three media largely negate these ones. It is striking, that FSP contained much more or much less statements about specific areas, like the cultural program, the Brazilians as a sportive nation, or doping and Russia, compared to the other three newspapers. The table also reveals the total difference in quantity between placed assertions, as it becomes clear in both statements B1 and B3, highlighted by color. In addition to the statements, there was special interest, laid in this investigation of the representation image of the Olympic Games in Rio de Janeiro in the international print media, who finally had made the declarations or statements (Table 12). In this respect, contrary to the preliminary studies by Gros (2001) and Fritzler (2015), the individual, preformulated remarks were checked for their authors in the present analysis. Regarding the statement on the host city (Table 13), it can be stated, that most of the contributions were made by journalists from the examined newspapers as well as from agencies. Together with athletes and 
inhabitants of the city, these two groups of authors largely negate the statement. Whereas the IOC, the Brazilian Organizing Committee, and the Brazilian politicians, are largely affirming the statement.

Table 12. Distribution of the sixteen pre-formulated statements appeared in the print media statement

\begin{tabular}{|c|c|c|c|c|}
\hline$\overline{\text { FAZ }}$ & NZZ & NYT & FSP & Tot \\
\hline $\mathrm{Y}$ & & & $\mathrm{Y}$ & $\mathrm{N}$ \\
\hline$\sum($ & $\sum(\mathrm{n})$ & $\sum(\mathrm{n})$ & $\sum(\mathrm{n})$ & $\sum$ \\
\hline & & 10 & & 00 \\
\hline
\end{tabular}

The Olympic Games will bring economic

benefits to the Brazilian people.

A

The increasing gigantism (also by media) has

a positive influence on the Olympic Games.

The cultural program is neglected at the Olympic Games.

\begin{tabular}{|c|c|c|c|c|}
\hline $\begin{array}{c}11418 \\
\mathbf{1 3 2}\end{array}$ & $\begin{array}{l}37 \quad 11 \\
48\end{array}$ & $\begin{array}{c}44 \quad 15 \\
59\end{array}$ & $\begin{array}{lll}5 & 2 \\
& 7 & \end{array}$ & $\begin{array}{c}20046 \\
246\end{array}$ \\
\hline 39 & $\begin{array}{ll}3 & 14\end{array}$ & $\begin{array}{ll}4 & 17\end{array}$ & $31 \quad 18$ & 42 \\
\hline
\end{tabular}

The city presents itself as a good host of the Olympic

Games (e.g. venues / water bodies in good condition).

The favelas in Rio reveal the shadows of the Olympic

$\mathrm{B}$

host city (e.g. crime / social inequity / poverty).

The new subway line is an enrichment

for the residents of Rio de Janeiro.

The safety for athletes / visitors in Rio de

Janeiro at the Olympic Games is ensured.

The hosts are fair, acclaim the performances of

international athletes (by cheering / applause).

The hosts are pleased to stage the Olympic Games.

$\mathrm{C}$

The hosts are a sport excited nation (like to do sports).

The Brazilians present themselves as good, helpful hosts, that warmly welcome Olympic athletes / visitors.

With its weak decision in the case of severe state doping problems in Russia, the IOC has lost last remnants of trust (into ist own institution).

In the IOC, conditions (corruption /

nepotism) prevail as at FIFA.

D With his decision (permission for Russians to start / exclusion of key witness(es) at the Games), Thomas Bach has set a fatal sign in the fight against doping.

The IOC has become more transparent and less scandalous (compared to past Olympic Games).

total

\begin{tabular}{|c|c|c|c|c|}
\hline 32 & 20 & 24 & 42 & 118 \\
\hline $\begin{array}{ll}57 & 7 \\
& 64\end{array}$ & $\begin{array}{lll}10 & 1 \\
& & \\
11 & \end{array}$ & $\begin{array}{ll}8 & 3 \\
& 11\end{array}$ & $\begin{array}{ll}10 & 9 \\
& \\
& 19\end{array}$ & $\begin{array}{l}8520 \\
105\end{array}$ \\
\hline $\begin{array}{l}34 \quad- \\
34\end{array}$ & $\begin{array}{lll}5 & - \\
& 5 & \end{array}$ & $\begin{array}{lll} & 1 & - \\
& & \\
& 1\end{array}$ & $\begin{array}{ll}7 & 3 \\
& 10\end{array}$ & $\begin{array}{ll}47 & 3 \\
50 & \end{array}$ \\
\hline $\begin{array}{ll}43 & 10 \\
& 53\end{array}$ & $\begin{array}{lll}8 & & 1 \\
& & \\
& 9 & \end{array}$ & $\begin{array}{ll}5 & - \\
& 5\end{array}$ & $\begin{array}{lr}7 & 6 \\
13 & \end{array}$ & $\begin{array}{ll}63 & 17 \\
80\end{array}$ \\
\hline $\begin{array}{c}16 \quad 136 \\
152\end{array}$ & $\begin{array}{l}4 \quad 16 \\
20\end{array}$ & $\begin{array}{ll}3 & \mathbf{2 3} \\
26 & \end{array}$ & $\begin{array}{c}10 \quad 16 \\
26\end{array}$ & $\begin{array}{c}33 \quad 191 \\
224\end{array}$ \\
\hline $\begin{array}{c}423 \quad 464 \\
887\end{array}$ & $\begin{array}{c}145 \quad \mathbf{1 8 9} \\
335\end{array}$ & $\begin{array}{c}153 \quad 239 \\
392\end{array}$ & $\begin{array}{c}355 \quad 239 \\
594\end{array}$ & $\begin{array}{c}10761132 \\
2208\end{array}$ \\
\hline
\end{tabular}


$Y=$ yes (affirmation of statement); $N=$ no (negation of statement); $\Sigma=$ sum (affirmed and negated statements); $n=$ quantity, (number of statements); $A=$ Olympic Games in general; $B=$ Olympic host city Rio de Janeiro; $C=$ Brazilian people as hosts; $D=$ International Olympic Committee (IOC); FIFA = Fédération Internationale de Football Association.

Table 13. Percentage distribution of statement 'B1 in Table 12' by authors

\begin{tabular}{|c|c|c|c|c|c|c|c|c|}
\hline author & $\begin{array}{c}\text { Journalist } \\
(\mathrm{n}=267) \\
\%\end{array}$ & $\begin{array}{c}\text { IOC } \\
(\mathrm{n}=10) \\
\%\end{array}$ & $\begin{array}{c}\text { Organizer }^{1} \\
(\mathrm{n}=9) \\
\% \\
\end{array}$ & $\begin{array}{c}\text { Citizen }^{2} \\
(\mathrm{n}=12) \\
\%\end{array}$ & $\begin{array}{c}\text { Politician }^{3} \\
(\mathrm{n}=18) \\
\%\end{array}$ & $\begin{array}{c}\text { Athlete } \\
(\mathrm{n}=27) \\
\%\end{array}$ & $\begin{array}{c}\text { Agency }^{4} \\
(\mathrm{n}=82) \\
\%\end{array}$ & $\begin{array}{c}\text { Total }(7) \\
(\mathrm{n}=450) \\
\%\end{array}$ \\
\hline Y & 19.3 & 1.6 & 1.6 & 0.4 & 2.7 & 2.7 & 3.3 & 33.6 \\
\hline $\mathrm{N}$ & 40.0 & 0.7 & 0.4 & 2.2 & 1.3 & 3.3 & 14.9 & 66.4 \\
\hline$\sum$ & 59.3 & 2.3 & 2.0 & 2.6 & 4.0 & 6.0 & 18.2 & 100 \\
\hline
\end{tabular}

Contemplating more precisely the statement 'recognition of the performance of international athletes by Brazilian audience' (Table 14), almost all registered authors negated the remark. Most of the statements came from journalists of the quality media, followed by athletes. Again, in this case, some numbers are partially underrepresented. Especially, the affirmative contribution of a tourist, is rather negligible in this context. The final statement presented in this article, regarding the author groups, deals with the IOC. Journalists, agency reporters, athletes, foreign politicians, and guest authors, mostly agree that the IOC has not become more transparent and scandal-free, compared to past Games. The IOC itself sees this fact, as the only author group, oppositely (Table 15). Both statements of a Russian and a Brazilian politician, are negligible in the listing. Most statements were delivered in this context by journalists and agency writers.

Table 14 - Percentage distribution of statement 'C1 in Table 12' by authors

\begin{tabular}{c|ccccc|c}
\hline author & $\begin{array}{c}\text { Journalist } \\
(\mathrm{n}=32) \\
\%\end{array}$ & $\begin{array}{c}\text { Guest }^{1} \\
(\mathrm{n}=2) \\
\%\end{array}$ & $\begin{array}{c}\text { Tourist }^{2} \\
(\mathrm{n}=1)\end{array}$ & $\begin{array}{c}\text { Athlete } \\
(\mathrm{n}=5)\end{array}$ & $\begin{array}{c}\text { Agency }^{3} \\
(\mathrm{n}=2)\end{array}$ & $\begin{array}{c}\text { Total (5) } \\
(\mathrm{n}=42) \\
\%\end{array}$ \\
\hline $\mathrm{Y}$ & 16.7 & - & $\mathbf{2 . 3}$ & 2.4 & - & 21.4 \\
$\mathrm{~N}$ & $\mathbf{5 9 . 5}$ & $\mathbf{4 . 8}$ & - & $\mathbf{9 . 5}$ & $\mathbf{4 . 8}$ & $\mathbf{7 8 . 6}$ \\
\hline$\sum$ & $\mathbf{7 6 . 2}$ & 4.8 & 2.3 & 11.9 & 4.8 & 100
\end{tabular}

1 = guest author; 2 = foreign person not Brazilian; 3 = journalist of agency; $Y=$ yes (affirmation of statement); $N=$ no (negation of statement); $\Sigma=\operatorname{sum}(Y+N) ; n=$ quantity (number of statements).

Table 15. Percentage distribution of statement 'D4 in Table 12' by authors

\begin{tabular}{c|cccccccc|c}
\hline author & $\begin{array}{c}\text { Journalist } \\
(\mathrm{n}=137)\end{array}$ & $\begin{array}{c}\text { IOC } \\
(\mathrm{n}=18)\end{array}$ & $\begin{array}{c}\text { Guest }^{1} \\
(\mathrm{n}=8)\end{array}$ & $\begin{array}{c}\text { Russian }^{2} \\
(\mathrm{n}=1)\end{array}$ & $\begin{array}{c}\text { Foreigner }^{3} \\
(\mathrm{n}=12)\end{array}$ & $\begin{array}{c}\text { Politician } \\
(\mathrm{n}=1)\end{array}$ & $\begin{array}{c}\text { Athlete } \\
(\mathrm{n}=11)\end{array}$ & $\begin{array}{c}\text { Agency } \\
(\mathrm{n}=32)\end{array}$ & $\begin{array}{c}\text { Total }_{(8)} \\
(\mathrm{n}=220)\end{array}$ \\
\hline $\mathrm{Y}$ & 4.5 & $\mathbf{5 . 9}$ & 0.5 & - & 0.9 & - & - & 2.3 & 14.1 \\
$\mathrm{~N}$ & $\mathbf{5 7 . 7}$ & 2.3 & $\mathbf{3 . 2}$ & $\mathbf{0 . 4}$ & $\mathbf{4 . 6}$ & $\mathbf{0 . 4}$ & $\mathbf{5 . 0}$ & $\mathbf{1 2 . 3}$ & $\mathbf{8 5 . 9}$ \\
\hline$\sum$ & $\mathbf{6 2 . 2}$ & 8.2 & 3.7 & 0.4 & 5.5 & 0.4 & 5.0 & 14.6 & 100
\end{tabular}

1 = guest author; 2 = Russian politician or person; 3 = foreign politician; $4=$ Brazilian politician; $5=$ journalist of agency; $Y=$ yes (affirmation of statement); $N=$ no (negation of statement); $\Sigma=$ sum $(Y+N) ; n=$ quantity, (number of statements). 


\section{DISCUSSION}

The extensive results of the present study illustrate, that the representation of the Olympic Games in Rio de Janeiro 2016, in the background reporting of the four international high-quality newspapers, overall, tends out more negative. However, it was treated and evaluated differently, in terms of quality and quantity, between the individual newspapers as well as at diverse, investigated variables. First, a previously stated hypothesis, that FSP publishes more articles on the Olympics than the rest of the media (43.2\% more than FAZ, 66.9\% more than NYT, $136.5 \%$ more than NZZ), has come true (Table 1). This significant difference, in the quantitatively higher coverage of the Brazilian newspaper, can certainly be attributed to the home factor, the closeness to the actual happenings as well as the identification with the event in their own country. The average more than twice as high proportion of published short messages, with $114.6 \%$, in FSP, compared to the other print media ( $87.5 \%$ more than NYT, $123 \%$ more than FAZ, $133.3 \%$ more than NZZ), throughout the complete analysis (Table 3), suggests, despite the high percentage of self-written contributions of about $70.6 \%$ averaged over all newspapers (Table 2), a more superficial and less opinion-critical, investigative journalism of the Brazilian FSP. Another previously made hypothesis, on the different thematic accentuation between the individual daily newspapers, has been confirmed (Table 4). The FAZ, NZZ and NYT reporting was significantly more affected by the subject doping, than FSP's coverage. Its thematic focus laid on the organization of the Games, followed by reports on hosts, safety situation, and general scandals. The main reason for the divergent weighting, as Crocitti and Vallance (2012) already noted, is due to a more on national affairs and local topics aligned news coverage of Brazilian daily newspapers. In this case, FSP has evidently preferred reports on corruption scandals of Brazilian construction companies, likewise, politicians and the associated organizational, political as well as economic problems at the Olympic Games, instead of reports on Russian state doping. Furthermore, other causes include the different media- and country-specific agenda-setting, framing, and priming processes or influences, on topic selection or setting in daily newspapers, as mentioned and highlighted by Scheufele (2000). The tendentially, negative prevailing presentation of the Rio Olympics in FAZ, NZZ und NYT, as well as the more neutral, ambivalent representation of the Games in FSP (Table 5), is based on an enhanced, critical discussion and negativism oriented, or shaped, news and topic selection, such as doping, in the non-Brazilian print media. The Brazilian journalists, however, have represented 'their Games' more positive, not least, because of their personal identification with the Games in their own country. A similar distribution, albeit more pronounced, is apparent, when regarding the results of the presentation trend of the host city Rio de Janeiro (Table 6). The many reports of NYT, FAZ and NZZ, concerning the precarious security situation in the city, because of terrorism worries, crime or a threatening Zika virus epidemic, moreover, regarding the lately completed subway line, generally bad transport conditions for visitors and athletes on site, and finally, reports on pollution of urban water bodies, let the host city of the XXXI. Summer Olympics appear predominantly and clearly negative, especially, in the run-up to the Games. In contrast to that, journalists of FSP saw pollution and transport concerns less impaired, furthermore, the overall security situation in the city more relaxed. This view is also shared by groups of people, who advocate the Games, such as the IOC, the organizers, or Brazilian politicians (Table 13). In the portrayal of the Brazilians, FSP presents its compatriots predominantly positive, as happy-cheering people (Table 7). However, due to the low fair play, and respect of Brazilian spectators, there existed many more negative reviews of the hosts in non-Brazilian daily papers (Table 10; Table 14). The booing of opponents at the Rio Olympics was a shocking violation of the fundamental principles of Olympism, or more precisely, points four and six in the Olympic Charter (Rohde, 2017). According to IOC (2017), the discrimination of any kind of athlete at the Olympic Games should be avoided and omitted. Even the disrespectful, non-solidarity behavior of the Brazilians, that one knew mostly from soccer, like the premature leaving of the arenas by many supporters, if their athlete or team was no more going to win in the foreseeable time of competition, did not pay tribute to the idea of the Olympic values. But just in this significant 
context, Coubertin (1910; 1935) always emphasized and highlighted the importance of fair play, called in his way 'religio athletae', as well as the mutual respect and understanding among nations, the so-called 'castle peace', respectively truce, during a competition, where national sentiments must be suspended or sent on a temporary holiday. Lenk (2008) also explicitly points out, that people have to give a more substantial, deeper feedback to the athletes, in fact: not winning is not a failure! Through the disturbing behavior of the Brazilian spectators, not the chivalrous participation is set in the foreground of athletes' minds, but only the physically - partly not legal - achieved victory. Thus, in short, a false value is implied and intensified, as Schantz (2015) illuminates: in our sport-frenetic society physical prowess often becomes an indicator of a person's value, not only in sport but also in other domains. This value understanding is jeopardizing Olympic ideas and values, and can affect, in the worst case, the use of unauthorized, for example technical or medicinal, expedients in sport. The IOC's representation in the print media, overall, was negative to very negative (Table 8). FAZ, NZZ and NYT were criticizing in its reporting the weak decisions of the IOC, regarding doping and Russia as well as the corruption of IOC members. In this point, especially, FAZ and NZZ express themselves extremely negative. In addition, FSP has also considered the ongoing criticism of the venue, general lack of support, and furthermore, the restrictive regulations by the IOC, as very negative. Several aspects, such as the introduction of an Olympic Refugee Team, have been welcomed and transported positive by the newspapers. However, it gets generally clear, that in the last few years, the IOC, contrary to its self-perception, has by no means become more transparent and scandal-free in the eyes of most groups of people (Table 12; Table 15). Therefore, it is hardly surprising that the function of the Games, as for the conveyance of values and international understanding, suffers, due to such unethical behavior of 'the guardians of the Olympic idea' (Table 9). These findings feed more and more the impression, that the Games are increasingly focusing and orientating on economic, media and commercial intentions conducted by the IOC, from which corresponding threats to the Olympic Movement arise. Ramon and Miragaya (2015) conclude, on their study to prominent themes of contemporary discussion related to the Olympic Movement, that there are ongoing problems and current concerns as commercialization, increasing costs, gigantism, doping, corruption, betting, decreasing bids, emphasis on the entertainment and spectacle, discrimination and no universality. In the present print media study, the majority of newspapers has revealed the apparently problematic influence of proceeding gigantism on the Games (Table 12), obviously favored through various forms of media (Table 11), particularly, of individual, global television broadcasters and media corporations. The winners or beneficiaries of the Olympic Games are diverse, as Preuss (2012) explains. However, many groups, that would be entitled to positive repercussions from the Games, do not benefit enough. For this reason, Grupe (2008) states in this context, that the mission statement of the Olympic sport must represent a counter-concept to the event sport, which is oriented to the interests of media, the entertainment industry and the market. According to this, a recollection to the Olympic values of Coubertin (1908; 1910), who already described the escalating, wagering effects in those days as a kind of 'cancer damage' for the Games, is required as well as a stronger focus on the values and goals of Hans Lenk (1972). Ibid. (2008) appealed almost a decade ago, that the Olympic 'telecracy' is not allowed to prevail, by sacrificing athletes' best training and competitive conditions in favor of increasingly prime-time televised media offerings. Unfortunately, the last Summer Olympic Games in Rio de Janeiro have specifically evinced this influence.

\section{CONCLUSIONS AND PROSPECTS}

The study exemplifies, that the print media presented a rather poor overall picture, more precisely overall image, of the Olympic Games in Rio de Janeiro 2016. Specific gained insights are confirmed by the current developments around the Games. The confidence, of Olympic applicants and outsiders, is gone. Nowadays, mindful citizens, who know the entanglements of capitalist market economy and Olympic presence, rebel more and more. Olympic projects fail row by row, not only because of the blatant concern about an 
unstoppable financial strength act, such as seen in the candidate cities Oslo 2022 or Rom 2024, but more recently also at the will of the people. The many current cancellations by potential host cities, like Munich 2022, Hamburg 2024, Innsbruck 2026 and most recently the Swiss canton Graubünden 2026, for the good two-week summer and winter sports events, is due to the massive headwind from the populations. Furthermore, the image of the Olympic Games in Rio de Janeiro as well as the reputation of the Olympic sports officials, were again diminished, by the recent revelations around former boss of Rio's Organizing Committee, Carlos Nuzman. Flagrant allegations of corruption, the firm suspicion of purchase of several votes for the first Games on South American ground, cost Nuzman now, just over a year after his emotional speech at the Opening Ceremony at Maracanã stadium, his job as National Olympic Committee chief of Brazil. These revelations are anything but inspiring to the Olympic Movement. The formation or initialization of a positive image, thus, moves more and more into the distance. The IOC wants to make a virtue out of necessity. It recently and conveniently awards Olympic Games as in a double pack. This procedure illustrates, how alarming the image of the Games really is today. Extraordinary circumstances, require extraordinary measures and reactions. In this context, Deister (2017) argues that in the present, troubling, and irrational era, which is increasingly marked by a climate of strife, disorder and recklessness as well as excessive fraud and pursuit of profit, the Olympic sport is searching for its own safeties, and this fact, not only represents the biggest challenge for it, but also more and more becomes a matter of survival. According to Kirsch-Schück (2016), the creation and formation of a rich future for the Olympic Movement, can only succeed, if it remembers its own roots, which requires a fundamental discussion of values, as recorded by the French Baron Pierre de Coubertin. According to this proposal, the study of Preuss et al. (2014) also discloses, the most named suggestions by Olympic scholars and experts to keep the Olympic Movement alive, which were in detail, descending of their frequency: set the focus on Olympic values, fight gigantism and commercialization, and establish a good governance policy. In order, to succeed a new mindset or recollection, critical voices, such as the Olympic appeals of Lenk (2008), must be listened to more carefully and turned into reality by those responsible. Especially, the latter point is currently being missed too much. Therefore, it still takes a long, stony, and fightfully process of all advocates, who have the belief in the ethical values and guiding principles of the Olympic idea, until a majoritically rethinking of athletes, coaches, officials, and persons in charge, really occurs. In times of momentary developments, admittedly, a seemingly futile struggle. But besides all despair, there is reason for hope. Particularly, in his thoughts about the Olympic leading idea, Coubertin (1908) has long since conjured the motivating spirit, figuratively, in the all too illusory seeming undertaking: the most important thing in life is not the triumph but the struggle, the essential thing is not to have conquered but to have fought well. Thus, always keep these motivating words in mind! While drawing up these last lines, the Olympic Movement already rushes inexorably towards its next major challenges. In less than 100 days, the XXIII. Winter Olympics begin in Pyeongchang, South Korea. No more 1,000 days to go, until the Olympic flame is ignited anew at the XXXII. Summer Olympics, for the second time, in the land of rising sun. After 56 years, Tokyo will, once again, host the world's biggest sports spectacle in 2020. Until the upcoming 'meetings of the world's youth', it remains to be seen, which announced measures and reforms the IOC has actually implemented, to enhance the image of the Games and itself, and how the echo of media and audience will turn out, over these and future venues.

\section{ACKNOWLEDGEMENTS}

I thank Emeritus Prof. Dr. Dr. N. Müller and Emeritus Prof. Dr. Dr. M. Messing, Johannes GutenbergUniversity Mainz, Germany, for many discussions and positive input. I profoundly thank Prof. Dr. N. Schneider-Todt for all support and the entire Olympic Studies Research Group, GPEO, Pontifícia Universidade Católica do Rio Grande do Sul Porto Alegre, Brazil, for assistance in generating data. 


\section{REFERENCES}

Adi, A. (2013). Media Regulations and the Olympic Charter: a history of visible changes. Journal of Olympic History, 21(1), 48-57.

Chappelet, J. J. (2014). Politics and the Olympics: a long lasting marriage arranged by Coubertin. In D. Chatziefstathiou \& N. Müller (Eds.), Olympism, Olympic Education and Learning Legacies (Chapter 14, pp. 133-143). Newcastle, UK: Cambridge Scholars Publishing.

Coubertin, P. de. (1908). Die Treuhänder der Olympischen Idee. Les Trustees de l'Idée Olympique. In CarlDiem-Institut DSHS Köln (Ed.) (1966), Der Olympische Gedanke. Reden und Aufsätze (pp. 2022). Schorndorf, Germany: Hofmann.

Coubertin, P. de. (1910). Ein modernes Olympia. Une Olympie moderne. In CarlDiem-Institut DSHS Köln (Ed.) (1966), Der Olympische Gedanke. Reden und Aufsätze (pp. 24-43). Schorndorf, Germany: Hofmann.

Coubertin, P. de. (1935). Die philosophischen Grundlagen des modernen Olympismus. Les assises philosophiques de I'Olympisme moderne. In CarlDiem-Institut DSHS Köln (Ed.) (1966), Der Olympische Gedanke. Reden und Aufsätze (pp. 150-154). Schorndorf, Germany: Hofmann.

Crocitti, J. J., Vallance, M. M. (2012). Brazil today: an encyclopedia of life in the republic. Santa Barbara, CA: ABC-CLIO.

Deister, G. (2017). Die Agenda 2028 des Thomas Bach. Doppelvergabe der Olympischen Spiele in einer Welt voller Unsicherheiten könnte Sicherheiten schaffen. Olympisches Feuer, 67(2), 18-22.

Fritzler, P. (2015). Die Berichterstattung der Komsomolskaja Prawda, der FAZ und der New York Times von den Olympischen Winterspielen in Sotschi in Bezug auf den Einfluss der Politik, die Rolle des IOK, die organisatorische Durchführung und die Gastgeberrolle Russlands: Eine inhaltsanalytische Betrachtung unter Einbeziehung einer Vergleichsstudie (unpublished master's thesis). Technical University, Kaiserslautern, Germany.

Früh, W. (1981). Inhaltsanalyse. Theorie und Praxis. München, Germany: Ölschläger.

Gros, K. (2001). Die olympischen Spiele von Sydney 2000 im Spiegel der internationalen Presse: Eine quantitative Inhaltsanalyse von ausgewählten Tageszeitungen aus fünf Ländern zur Darstellung Australiens, der Gastgeberstadt und dem veranstaltenden IOC (unpublished master's thesis). Johannes Gutenberg University, Mainz, Germany.

Grupe, O. (2008). Das olympische Leitbild prägt nicht nur die Olympischen Spiele. Olympisches Feuer, 58(1), $14-18$.

International Olympic Committee. (2017). Olympic Charter. In force as from 15 September 2017. Lausanne, Switzerland: DidWeDo S.à.r.l.

Kirsch-Schück, K. (2016). Es geht um eine neue Wertediskussion. Olympisches Feuer, 66(3), 18.

Krippendorff, K. (1981). Content Analysis. An Introduction to Its Methodology (2nd ed.). The Sage CommText Series, 5. Beverly Hills, CA, London, UK: Sage Publications.

Lenk, H. (2008). Üb Erleben! Denn nicht gewinnen ist kein Scheitern. Ein olympischer Appell an Athleten und andere Aktive. Olympisches Feuer, 58(3), 18-20.

Lenk, H. (1972). Werte, Ziele, Wirklichkeit der modernen Olympischen Spiele (2nd ed.). Schorndorf, Germany: Hofmann.

Lennartz, K. (2014). From Symbol of Idealism to Money-Spinner. Journal of Olympic History, 22(1), 515.

Likert, R. (1932). A technique for the measurement of attitudes. Archives of Psychology, 22(140), 1-55.

Luhmann, N. (1996). Die Realität der Massenmedien (2nd ed.). Opladen, Germany: Westdeutscher Verlag. https://doi.org/10.1007/978-3-663-01103-3 
Mayring, P. (1983). Qualitative Inhaltsanalyse - Grundlagen und Techniken. Weinheim, Germany, Basel, Switzerland: Beltz.

Preuss, H. (2012). Olympische Spiele der Neuzeit als Wirtschaftsfaktor. Wer profitiert von den Olympischen Spielen? Working Paper Series: Mainzer Papers on Sports Economics \& Management (no. 9). Mainz, Germany: Johannes Gutenberg University.

Preuss, H., Schütte, N., Könecke, T., \& Dacosta, L. (2014). Olympic Ideals as seen by Olympic Scholars and Experts. Working Paper Series: Mainzer Papers on Sports Economics \& Management, (no. 13). Mainz, Germany: Johannes Gutenberg University.

Ramon, X., \& Miragaya, A. (2015). Olympic Idea nowadays: unravelling major themes and approaches from selected Olympic scholars. In D. Chatziefstathiou, X. Ramon \& A. Miragaya (Eds.), Olympic Idea Nowadays. Perceptions and insights (pp. 21-29). Universitat Autònoma de Barcelona, Spain: Centre d'Estudis Olímpics i de l'Esport.

Rohde, E. (2017). The Olympic Games in Rio de Janeiro 2016 in the focus of representative newspapers from three countries (unpublished master's thesis). Technical University, Kaiserslautern, Germany.

Scheufele, D. A. (2000). Agenda-Setting, Priming, and Framing Revisited: Another Look at Cognitive Effects of Political Communication. Mass Communication and Society, 3(2-3), 297-316. https://doi.org/10.1207/S15327825MCS0323_07

Schulz, W. (2008). Politische Kommunikation: theoretische Ansätze und Ergebnisse empirischer Forschung (2nd ed.). Wiesbaden, Germany: VS.

\section{(ㅇ) $(\mathbb{\theta} \Theta \Theta$}

This title is licensed under a Creative Commons Attribution-NonCommercial-NoDerivs 3.0 Unported License. 